\title{
PERKEMBANGAN BUNGA, BUAH DAN KEBERHASILAN REPRODUKSI JENIS SAGA (Adenanthera pavonina L.)
}

\author{
(Stage of Flower, Fruit and Reproductive Success of Adenanthera pavonina L.) \\ Kurniawati Purwaka Putri ${ }^{1)}$ dan Agus Astho Pramono ${ }^{1)}$ \\ Balai Penelitian Teknologi Perbenihan Tanaman Hutan \\ ${ }^{1)} J 1$. Pakuan, Ciheuleut PO BOX 105 Bogor 16001, Tep/Fax. 0251327768 \\ Email : niapurwaka@yahoo.co.id; asthopramono@yahoo.co.id
}

Naskah masuk : 25 Juni 2012; Naskah diterima : 17 Mei 2013

\begin{abstract}
The information of flower and fruit development and the reproduction success rate of Adenanthera pavonina plant is important to increase the production of seeds. The objectives of this research were to determine (1) the development of A. pavonina's fruit and flower and (2) the rate of reproduction success. The research was conducted in Bogor, Cikampek and Yogyakarta. Observations were done on changes of color, shapes and sizes as well as calculated the time period of each stage of development. Stages of development observed ranging from flowers to bloom. Stages of the development of the flowers observed started from bud up to the bloom of the flowers. The reproduction success marked by calculating the average number of flowers per branch and the amount of flowers' ovule. The results showed that A. pavonina's flower buds were shaped of grains in one series. The structure of the A. pavonina flower are hermaphrodites. The period of time needed to form the flower buds up to small (pieces) pods was 25 days. Development of small pods up to solid pods took 64 days. Total time to form flowers and fruit were 89 days or about 3 months. A. pavonina's reproduction succes were low which is $0.89 \%$. The number of pods (malai) varied between 1 and 8 pieces; based on that A. pavonina's fruit set can be improved by increasing the success of pollination and cross out, through increasing the number of trees, genetic diversity, and the density of trees.
\end{abstract}

Keywords: Adenanthera pavonina, flowering, fruiting, reproductive success

\begin{abstract}
ABSTRAK
Informasi perkembangan bunga dan buah serta tingkat keberhasilan reproduksi tanaman Adenanthera pavonina sangat diperlukan dalam upaya meningkatkan produksi biji atau benihnya. Tujuan penelitian adalah mengetahui perkembangan buah dan bunga A. pavonina serta tingkat keberhasilan reproduksi. Penelitian dilaksanakan di tiga lokasi yang berbeda yaitu Bogor, Cikampek dan Yogyakarta. Metode penelitian adalah observatif. Pengamatan yang dilakukan meliputi pengamatan perubahan warna, bentuk dan ukuran serta menghitung periode waktu dari setiap tahapan perkembangan tersebut. Tahapan perkembangan bunga yang diamati mulai dari tunas bunga hingga bunga mekar. Tahapan perkembangan buah yang diamati mulai dari bakal buah, terjadinya buah, buah muda, hingga buah masak. Keberhasilan reproduksi diketahui dengan menghitung rata-rata jumlah bunga per ranting dan jumlah ovule per bunga pada 3-4 ranting dari beberapa pohon yang sedang berbunga. Hasil penelitian menunjukkan bahwa bunga kuncup A. pavonina berbentuk bulir-bulir dalam satu rangkaian (malai). Berdasarkan struktur bunganya, tanaman $A$. pavonina bersifat hermaphrodites. Periode waktu yang dibutuhkan dari kuncup bunga hingga buah/polong kecil adalah 25 hari. Perkembangan polong kecil hingga polong berisi benih padat dan akhirnya pecah memerlukan waktu 64 hari. Total perkembangan pembentukan bunga dan buah memerlukan waktu 89 hari atau sekitar 3 bulan. Keberhasilan reproduksi A. pavonina masih rendah yaitu $0,89 \%$. Jumlah polong/malai bervariasi antara 1 dan 8 buah, oleh karena itu fruit set $A$. pavonina masih dapat ditingkatkan dengan meningkatkan keberhasilan penyerbukan dan silang luar, melalui peningkatan jumlah pohon, keanekaragaman genetik, dan kerapatan pohon.
\end{abstract}

Kata kunci : Adenanthera pavonina, keberhasilan reproduksi, pembungaan, pembuahan

\section{PENDAHULUAN}

Adenanthera pavonina L. dari Famili Leguminosae merupakan tanaman asli dari India yang sudah beradaptasi lama dengan iklim di Indonesia. A. pavonina atau yang dikenal dengan nama saga pohon hidup dengan baik di tempat-tempat yang terbuka dan terkena sinar matahari secara langsung, baik di dataran rendah maupun dataran tinggi pada ketinggian 1-600 m dpl (Heyne, 1987).

Pohon A. pavonina memiliki manfaat yang 
serbaguna karena hampir semua bagian tanaman dapat digunakan dan bernilai ekonomis. Batang pohon A. pavonina dapat dimanfaatkan sebagai bahan bangunan dan mebel. Selain itu, nilai energi kayu saga mencapai $6.628 \mathrm{cal} / \mathrm{g}$, maka kayu $A$. pavonina sangat baik untuk dimanfaatkan sebagai kayu bakar dan bahan pembuatan arang (Kurniaty et al. 2011), sedangkan bijinya mempunyai komposisi nutrisi (protein, lemak dan karbohidrat) relatif tinggi yang hampir sama dengan kacang kedelai. Penilaian terhadap kandungan protein menunjukkan kualitas yang baik, dengan asam amino esensial relatif lengkap dan menunjukkan konsentrasi tinggi (Oey et al., 1981, dalam Adimunca, 1988). Biji A. pavonina memiliki komposisi asam lemak tidak jenuh $(82,24 \%)$ yang lebih tinggi dari asam lemak jenuh $(17,76$ \%) (Lembaga Kimia Nasional, 1983) sehingga berpotensi sebagai sumber energi terbarukan (biodisel). Timnas Pengembangan BBN (2008) menyatakan bahwa saga memiliki potensi yang cukup menjanjikan sebagai biodiesel diantaranya karena daging biji yang mengandung 14-28\% minyak lemak yang tergolong Non Pangan. Selain berpotensi sebagai biodiesel, minyak dari biji A. pavonina sangat baik untuk mengobati penyakit dalam, kudis, luka-luka, pembuatan lilin, industri batik, dan bahan membuat sabun (Kurniaty etal., 2011).

Berdasarkan kemanfaatan dari tanaman $A$. pavonina tersebut, maka perlu adanya pengembangan melalui kegiatan penanaman khususnya pada daerah-daerah yang membutuhkan bahan bakar untuk pengembangan industri atau daerahdaerah yang menghadapi keterbatasan dalam pasokan bahan bakar untuk kegiatan rumah tangga. Pengembangan saga pohon sebagai sumber energi memerlukan pemahaman yang komprehensif dari teknik budidaya, teknik produksi, hingga teknik pemanfaatnnya. Untuk mendukung pe- nyediaan informasi tentang teknik pengadaan bibit dan teknik produksi buah saga, maka diperlukan pemahaman tentang potensi dan kendala produksi benih saga antara lain tahapan-tahapan perkembangan organ reproduktif, dan periode waktu yang dibutuhkan dari setiap tahapan perkembangan tersebut, serta tingkat keberhasilan reproduksinya. Pemahaman tentang keberhasilan reproduksi dari saga diperlukan dalam menentukan strategi tentang jumlah pohon, keragaman genetik dan kerapatan pohon yang diperlukan dalam rangka pengembangan tanaman $A$. pavonina, sebagai penghasil benih atau sebagai penghasil biji dengan kualitas dan kuantitas yang optimal. Keberhasilan reproduksi dapat diprediksi dengan mengetahui proses pembungaan seperti musim, waktu, periode dan juga intensitas dari pembungaan dan pembuahan suatu jenis (House, 1977).

Tujuan penelitian ini adalah untuk (1) mengetahui waktu dan tahapan perkembangan generatif Adenanthera pavonina yang meliputi karakteristik struktur bunga dan tahapan perkembangan bunga sampai buah serta (2) mengetahui nilai keberhasilan reproduksi.

\section{METODE PENELITIAN}

\section{A. Waktu dan Tempat Penelitian}

Penelitian dilaksanakan mulai bulan Maret sampai Oktober 2011. Lokasi penelitian pengamatan perkembangan organ generatif $A$. pavonina terletak di Desa Babakan, Kecamatan Bogor Tengah, Propinsi Jawa Barat. Sedangkan untuk penelitian keberhasilan reproduksi selain di lokasi Bogor juga dilakukan di 2 tempat lainnya yaitu di Desa Kamojing Kabupaten Cikampek dan di Desa Tlogo Prambanan Kecamatan Prambanan Kabupaten Klaten Propinsi DI Yogjakarta. Data

Tabel (Table) 1. Risalah tempat tumbuh tegakan A. pavonina (Site description of A. pavonina plant)

\begin{tabular}{|c|c|c|c|c|c|}
\hline $\begin{array}{c}\text { Lokasi } \\
\text { (Location) }\end{array}$ & $\begin{array}{c}\text { Ketinggian } \\
\text { tempat } \\
\text { (Altitude) } \\
(\mathrm{m} d \mathrm{dpl}) \\
(m d p l)\end{array}$ & $\begin{array}{l}\text { Curah hujan } \\
\text { tahunan } \\
\text { (annual } \\
\text { rainfall) } \\
\text { mm/tahun } \\
\text { (mm/year) }\end{array}$ & $\begin{array}{c}\text { Suhu } \\
\text { (Temperature) } \\
\left({ }^{\circ} \mathrm{C}\right)\end{array}$ & $\begin{array}{c}\text { Kelembaban } \\
\text { nisbi (Relative } \\
\text { humidity) } \\
(\%)\end{array}$ & $\begin{array}{l}\text { Intensitas matahari } \\
(\text { Sun intensity) } \\
\left(\mathrm{Cal} / \mathrm{cm}^{2} / \mathrm{menit}^{2}\right) \\
\left(\mathrm{Cal}^{2} \mathrm{~cm}^{2} / \text { minute }^{2}\right)\end{array}$ \\
\hline $\begin{array}{l}\text { Ds. Babakan Kec. } \\
\text { Bogor Barat Bogor }\end{array}$ & 207 & 3.633 & 25,6 & 83,5 & 286,2 \\
\hline $\begin{array}{l}\text { Ds. Kamojing Kab } \\
\text { Cikampek }\end{array}$ & $<100$ & 1.084 & 27 & 80 & - \\
\hline $\begin{array}{l}\text { Ds. Tlogo Kec. } \\
\text { Prambanan Kab. } \\
\text { Sleman, DI } \\
\text { Yogjakarta }\end{array}$ & 154 & $2.000-3.000$ & 28 & - & - \\
\hline
\end{tabular}


kondisi iklim secara rinci setiap bulan selama tahun 2011 disajikan dalam Lampiran 1.

\section{B. Bahan Penelitian}

Bahan yang digunakan dalam penelitian ini adalah pohon $A$. pavonina dengan rata-rata diameter pohon di Bogor, Cikampek dan Yogjakarta masing-masing sebesar 48,09 \pm 7,6 cm; 15,23 \pm $10,43 \mathrm{~cm} ; 31,9 \pm 8,6 \mathrm{~cm}$. Rata-rata tinggi total adalah $15,8 \pm 1,1 \mathrm{~m} ; 12,11 \pm 1,52 \mathrm{~m} ; 10,5 \pm 1,7$ m. Bahan lain yang digunakan adalah larutan FAA (Formalin Acetic Acid) yang terdiri dari alkohol $70 \%$, asam cuka, formalin serta aquades. Alat-alat yang digunakan adalah tangga, golok, gunting stek, kamera, label kertas, plastik, penggaris dan alat-alat tulis lainnya.

\section{Metode Penelitian}

\section{Pengamatan tahapan perkembangan bunga}

Pengamatan dilakukan terhadap calon bunga yang terdapat pada 3-4 dahan produktif dari 7 pohon sampel yang dilakukan secara acak. Tahapan yang diamati mulai dari terlihatnya tunas bunga hingga bunga mekar (anthesis). Pengamatan yang dilakukan meliputi perubahan warna, bentuk dan ukuran serta menghitung jangka waktu perubahan setiap tersebut. Pengamatan juga dilakukan terhadap karakterteristik organ reproduksi jantan (stamen dan polen) dan organ reproduksi betina (stylus, ovarium dan stigma). Pengamatan dilakukan setiap hari (untuk mengetahui jangka waktu dan lamanya masing-masing tahap perkembangan bunga dan buah)

\section{Pengamatan tahapan perkembangan buah}

Pengamatan perkembangan pembuahan mulai dari terlihatnya tanda bakal buah (tunas generatif), terjadinya buah, buah muda, hingga buah masak. Pengamatan yang dilakukan meliputi perubahan warna, bentuk dan ukuran serta menghitung jangka waktu perubahan setiap tersebut.

\section{Pengamatan keberhasilan reproduksi}

Untuk kegiatan Pengamatan Keberhasilan Reproduksi ini pengamatan dilakukan di 3 lokasi yang berbeda yaitu Bogor, Cikampek dan Yogjakarta. Pengamatan dilakukan pada 3 - 4 ranting dari beberapa pohon yang sedang berbunga pada setiap tegakan sampel. Jumlah ranting dan jumlah pohon yang diamati sama dengan pengamatan jumlah bunga. Pada masing-masing pohon sampel dilakukan penghitungan rata-rata jumlah bunga per ranting dan jumlah ovule per bunga. Keberhasilan reproduksi (Reproductive Success/
$R S$ ) dihitung dengan menggunakan rumus (Owen etal., 1991):

$$
\mathrm{RS}=\mathrm{Fr} / \mathrm{Fl} \times \mathrm{S} / \mathrm{O}
$$

dimana: $\mathrm{RS}=$ keberhasilan reproduksi (reproduction succes)

$\mathrm{Fr}=\operatorname{buah}($ fruit $) /$ malai

$\mathrm{Fl}=$ bunga $($ flower $) /$ malai

$\mathrm{S}=\operatorname{benih}($ seed $) /$ polong

$\mathrm{O}=$ Ovule/bunga

\section{HASIL DAN PEMBAHASAN}

\section{A. Hasil}

\section{Tahapan perkembangan bunga-buah}

Secara umum, tahapan perkembangan organ generatif $A$. pavonina (bunga-buah) terbagi dalam 5 fase yaitu (1) pembentukan bunga; (2) penyerbukan dan pembentukan buah/benih; (3) pertumbuhan buah; (4) pemasakan buah/benih; dan (5) penyebaran (dispersal). Hasil pengamatan terhadap perkembangan bunga-buah pada pohon A. pavonina mulai dari bunga kuncup hingga terbentuknya buah (polong) masak dapat dilihat pada Tabel 2 dan Gambar 1.

\section{Keberhasilan reproduksi (KR)}

Keberhasilan reproduksi menunjukkan persentase keberhasilan bunga yang terserbuki untuk berkembang hingga menjadi buah masak. Rata-rata nilai keberhasilan reproduksi A. pavonina yang terdapat di Bogor, Cikampek dan Yogyakarta disajikan pada Tabel 3.

Dari pengamatan perkembangan pembungaan pembuahan yang dilakukan di Desa Babakan, Kecamatan Bogor Tengah, diketahui bahwa pembungan mulai terjadi pada akhir bulan Maret dan musim buah matang pada bulan Juni. Namun berbeda halnya dengan musim pembungaan pembuahan tanaman $A$. pavonina yang berada di Desa Kamojing Cikampek, dimana pada waktu yang sama (bulan Juni) hampir sebagian besar tanaman saga di daerah tersebut dalam fase mulai berbunga mekar. Sehingga apabila berdasarkan hasil dari tahap perkembangan bunga di Bogor, diperkirakan di Cikampek buah masak akan terjadi September Oktober. Akan tetapi ternyata pada bulan Oktober diketahui bahwa musim buah telah lewat. Informasi penduduk setempat diperkirakan bahwa musim buah terjadi pada bulan Agustus-September atau tepatnya 2-3 bulan lebih cepat. 
Tabel(Table) 2. Tahapan perkembangan pembungaan pembuahan pohon A. pavonina (Developmental stages of flowering and fruiting of A. pavonina)

\begin{tabular}{|c|c|c|}
\hline $\begin{array}{c}\text { Fase } \\
(\text { Stages }) \\
\end{array}$ & $\begin{array}{c}\text { Kondisi bunga-buah } \\
(\text { Flower-fruit condition })\end{array}$ & $\begin{array}{l}\text { Periode (hari) } \\
\text { Period (days) }\end{array}$ \\
\hline $\begin{array}{l}\text { Pembentukan bunga } \\
\text { (Fruit formation) }\end{array}$ & $\begin{array}{l}\text { Bunga kuncup hingga bunga mekar } \\
\text { (Flower buds up to flower's blooms) }\end{array}$ & $13(8-12)$ \\
\hline $\begin{array}{l}\text { Penyerbukan dan Pembentukan } \\
\text { buah/benih } \\
\text { (Pollination and seed } \\
\text { formation) }\end{array}$ & $\begin{array}{l}\text { Bunga mekar hingga polong kecil } \\
\text { (Flower's blooms up to small fruits) }\end{array}$ & $12(8-15)$ \\
\hline $\begin{array}{l}\text { Perkembangan buah } \\
\text { (Fruit development) }\end{array}$ & $\begin{array}{l}\text { Polong kecil hingga polong berisi benih lunak } \\
\text { (Small pods up to pods containing soft seeds) }\end{array}$ & $12(10-14)$ \\
\hline $\begin{array}{l}\text { Perkembangan buah masak } \\
\text { (Seed maturation) }\end{array}$ & $\begin{array}{l}\text { Polong berisi benih lunak hingga berisi benih padat } \\
\text { (Pods containing soft seed up to pods containing hard } \\
\text { seed) }\end{array}$ & $9(7-12)$ \\
\hline & $\begin{array}{l}\text { Polong berisi benih padat berwarna hijau hingga polong } \\
\text { berwarna hitam } \\
\text { (Green pods containing hard seed up to black pods) }\end{array}$ & $26(21-30)$ \\
\hline Penyebaran (Dispersal) & $\begin{array}{l}\text { Polong hitam hingga polong pecah } \\
\text { (Black pods up to opened pods) }\end{array}$ & $17(15-21)$ \\
\hline & Total & $89(69-104)$ \\
\hline
\end{tabular}
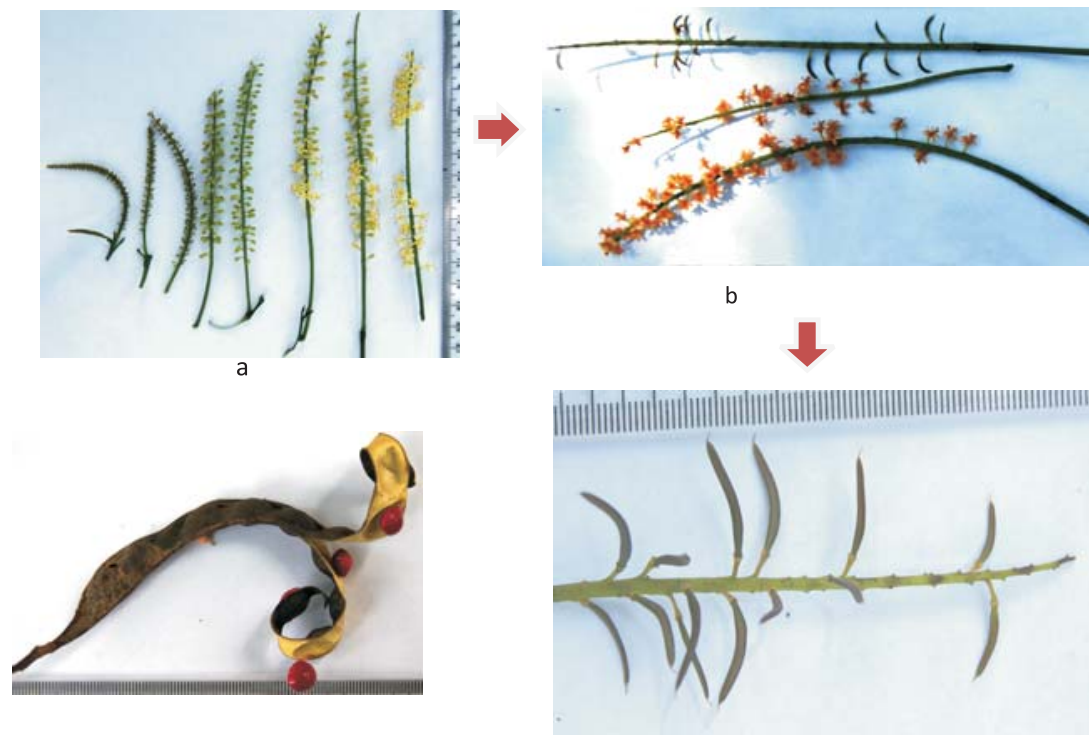

e

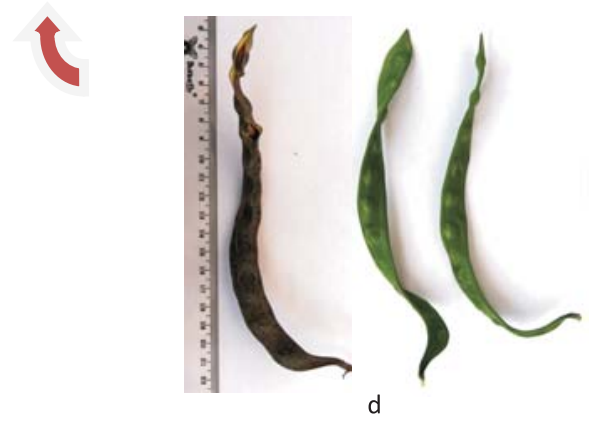

Gambar(Figure) 1. Perkembangan pembungaan pembuahan tanaman A. pavonina mulai (a) bunga kuncup sampai bunga mekar; (b) bunga yang telah diserbuki; (c) buah/polong muda; (d) polong yang telah berisi benih; (e) polong masak (The developmental offlowering and fruiting of A. pavonina (a) flower bud and flower burst; (b) pollinated flowers; (c) young fruits; (d) fruits with developed seeds;(e) mature fruit) 
Tabel(Table)3. Keberhasilan Reproduksi A. pavonina di Bogor, Cikampek dan Yogyakarta (The reproductive success of A. pavonina at Bogor, Cikampek and Yogyakarta)

\begin{tabular}{|c|c|c|c|c|c|c|c|}
\hline $\begin{array}{c}\text { Lokasi } \\
\text { (Location) }\end{array}$ & $\begin{array}{l}\text { Jumlah bunga/ } \\
\text { malai (Number of } \\
\text { flowers/panicle) }\end{array}$ & $\begin{array}{c}\text { Jumlah } \\
\text { polong/ } \\
\text { Malai } \\
\text { (Number of } \\
\text { fruits/ } \\
\text { panicle) }\end{array}$ & $\begin{array}{l}\text { Pembentuka } \\
\text { n buah } \\
\text { (Fruit set) } \\
(\%)\end{array}$ & $\begin{array}{l}\text { Jumlah ovul/ } \\
\text { Polong } \\
\text { (Number of } \\
\text { ovuls/fruit) }\end{array}$ & $\begin{array}{l}\text { Jumlah benih/ } \\
\text { polong } \\
\text { (Number of } \\
\text { seed/fruit) }\end{array}$ & $\begin{array}{c}\text { Pembentukan } \\
\text { benih } \\
\text { (Seed set) } \\
(\%)\end{array}$ & $\begin{array}{c}\text { Keberhasilan } \\
\text { reproduksi } \\
\text { (Reproductive } \\
\text { success) } \\
(\%)\end{array}$ \\
\hline Bogor & $278,43 \pm 130,62$ & $2,0 \pm 1,1$ & 1,11 & $10,8 \pm 1,9$ & $9,2 \pm 2,1$ & 85,05 & 0,94 \\
\hline Yogyakarta & $254,75 \pm 27,58$ & $2,42 \pm 0,77$ & 0,95 & $10,85 \pm 0,67$ & $10,27 \pm 0,92$ & 94,48 & 0,93 \\
\hline Cikampek & 305,7 & $2,48 \pm 1,93$ & 0,81 & $10,10 \pm 2,21$ & $10,05 \pm 2,22$ & 99,99 & 0,81 \\
\hline
\end{tabular}

\section{B. Pembahasan}

\section{Tahapan perkembangan bunga-buah}

Fase atau tahap pembentukan bunga merupakan suatu tahapan perkembangan awal dari pembungaan pembuahan yang dimulai dari terbentuknya tunas generatif atau tunas primordia bunga (apeks meristem reproduksi) hingga bunga mekar (anthesis). Hasil penelitian menunjukkan bahwa tunas bunga $A$. pavonina terletak pada ketiak daun (axillary), berwarna hijau dengan panjang sekitar $0,1-0,2 \mathrm{~cm}$. Pada jenis tanaman ini tunas generatif muncul bersamaan dengan tunas vegetatif atau tunas primordia daun (apeks meristem vegetatif). Tunas bunga $A$. pavonina kemudian berkembang menjadi bunga kuncup yang berbentuk bulir-bulir dan tersusun memanjang dalam satu rangkaian bunga yang disebut malai (compound inflourescences). Jumlah bunga kuncup dalam setiap malai berkisar 121-427 butir dengan panjang malai $7-22 \mathrm{~cm}$. Selanjutnya bunga kuncup $A$. pavonina membesar yang diikuti dengan pertambahan ukuran panjang malai serta perubahan warna kuncup yang pada awalnya berwarna hijau hingga akhirnya berwarna hijau kekuningan. Kuncup bunga yang membesar menandakan sedang berlangsungnya proses pembentukan dan perkembangan ovari serta alat reproduksi yaitu putik dan benang sari (Sedgley dan Griffin, 1989).

Bunga selanjutnya mekar (anthesis). Proses mekarnya bunga terjadi secara bertahap mulai dari pangkal menuju ke pucuk malai (bersifat acropetally). Jumlah bunga mekar dalam setiap malai berkisar antara 230-290 bunga. Bunga $A$. pavonina yang telah mekar berwarna kuning. Rata-rata waktu yang dibutuhkan hingga bunga A. pavonina mulai mekar adalah 13 hari.

Tanaman A. pavonina termasuk tanaman hermaphrodites yaitu organ reproduski jantan (putik/ stylus) dan organ reproduksi betina (benang sari/ stamen) terdapat dalam satu bunga. Kelopak bunga berbentuk corong berwarna hijau pucat. Mahkota bunga (sepal/corolla) berwarna kuning berbentuk bintang yang berjumlah 4-5 helai. Benang sari berjumlah 8-10 dengan tangkai benang sari (filament) panjang $\pm 1 \mathrm{~cm}$ berwarna kuning pucat. Kepala sari (anther) berwarna coklat muda. Struktur bunga A. pavonina selengkapnya disajikan pada Gambar 2.

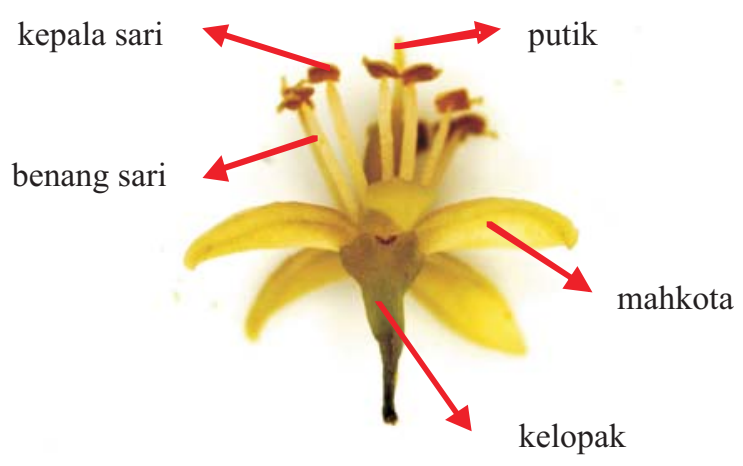

Gambar (Figure) 2. Struktur bunga A. pavonina (Structure of A.pavonina flower) 
Pada tanaman A. pavonina tata letak bunga betina (putik) lebih tinggi dibandingkan bunga jantan (benang sari). Perpanjangan putik tersebut merupakan salah satu mekanisme memperlancar terjadinya outcossing, dengan cara menjauhkan anther dan kepala putik pada tahap perkembangan organ betina (Moncur dan Boland, 1989). Oleh karena itu untuk proses penyerbukan diperlukan bantuan agen penyerbuk atau polinator. Berdasarkan struktur bunga yang berbentuk malai dan jumlah bunga yang banyak serta dengan bau dan warna mencolok, maka diduga polinator tanaman A. pavonina adalah serangga.

Fase penyerbukan dan pembentukan buah/ benih dimulai sejak terjadi penyerbukan atau menempelnya benang sari (pollen) pada kepala putik (stigma). Bunga A. pavonina yang telah terserbuki dapat dibedakan dari mahkota bunganya yang berwarna orange. Proses perkembangan tersebut terjadi selama $8-15$ hari atau rata-rata 12 hari.

Setelah terjadi penyerbukan maka dimulailah fase pertumbuhan buah/benih. Buah A. pavonina berbentuk polong. Rata-rata ukuran panjang polong yang masih kecil adalah $0,8 \mathrm{~cm}$. Polong $A$. pavonina tumbuh dan berkembang hingga menjadi polong yang berisi benih lunak, dan kemudian berubah menjadi polong yang padat dan berwarna hijau segar. Setiap polong berisi 10-12 butir biji. Periode waktu yang dibutuhkan selama fase ini sangat panjang yaitu 47 hari (38-56 hari) karena terjadinya proses pertumbuhan polong mulai dari berukuran panjang $0,8 \mathrm{~cm}$ hingga akhirnya mencapai panjang 15-20 cm dengan kondisi mulai belum berisi ovul atau benih hingga berisi benih padat. Kemudian polong yang berwarna hijau berangsur-angsur berubah warna menjadi hitam. Rata-rata waktu yang dibutuhkan hingga menjadi polong berwarna hitam adalah 17 hari (15-21 hari).

Tahapan akhir dari proses perkembangan bunga buah saga adalah fase penyebaran benih (dispersal). Tahapan ini ditandainya dengan polong kering berwarna coklat kehitaman dan pecah dengan sendirinya. Rata-rata waktu yang dibutuhkan dari polong utuh hingga polong mulai pecah selama 17 hari. Sehingga waktu yang diperlukan dari mulai terbentuknya kuncup bunga yang berbentuk bulir hingga polong pecah mencapai 69104 hari atau sekitar $2-3,5$ bulan dengan rata-rata 89 hari atau sekitar 3 bulan.

\section{Keberhasilan reproduksi (KR)}

Pada hasil penelitian ini rata-rata tingkat ke- berhasilan reproduksi A. pavonina sebesar 0,89\%. Berdasarkan nilai klasifikasi Owens (1993) hasil tersebut termasuk kategori rendah karena berada di bawah $30 \%$. Salah satu penyebab rendahnya produksi benih $A$. pavonina adalah rendahnya persentase keberhasilan bunga untuk berkembang menjadi buah (fruit set) yang diduga dipengaruhi oleh rendahnya keberhasilan penyerbukan atau rendahnya kawin silang (cross pollination). Hal tersebut dapat dilihat dari perbandingan jumlah buah/malai, benih/buah dan ovul/ buah yang dilakukan di Bogor dan Yogyakarta (Tabel 3). Rendahnya pembentukan buah karena penyerbukan sendiri (self pollination) pernah diteliti pada pohon argan (Argan spinosa) yaitu sebesar $0,51 \%$ pada self pollination dan $6,47 \%$ pada cross pollination (Nerd et al., 1998). Self pollination yang terjadi pada bunga, dan gugurnya buah muda dapat dikurangi melalui pengaturan jarak tanam dan peningkatan jumlah pollinator (Owens, 1993). Pada kasus jenis A. pavonina ini faktor yang mempengaruhi penyerbukan diduga karena saga tidak ditanam dalam bentuk hutan tanaman yang rapat, A. pavonina pada umumnya ditemukan dalam populasi yang kecil dan terpencar dengan jarak tanam yang jauh sehingga kemungkinan terjadinya self pollination tinggi.

Kisaran jumlah polong per malai di Yogyakarta adalah 1-9 polong/malai, di Bogor 1-7 polong, dan Cikampek 1-7/polong. Namun demikian terlihat adanya peluang bahwa produksi biji saga dapat ditingkatkan karena kondisi fruit set di semua tegakan yang diamati belum optimal. Upaya-upaya yang dapat mendukung peningkatan fruit set seperti peningkatan jumlah pohon, keragaman genetik dan kerapatan pohon perlu dilakukan dalam pengembangan A. pavonina sebagai penghasil benih atau sebagai penghasil biji. Keragaman genetik dan kerapatan yang tinggi akan mendukung terjadinya perkawinan silang pada tanaman. Populasi tanaman yang tinggi juga akan mendorong peningkatan populasi serangga penyerbuk sehingga meningkatan keberhasilan penyerbukan. Hal ini diperkuat Murawski et al. (1994) dalam Kartikawati (2008) yaitu pada jenis tanaman Shorea megistophylla dimana tegakan dengan kerapatan tinggi memiliki nilai penyerbukan silang (outcrossing rate) yang lebih tinggi dibandingkan pada tegakan yang telah dijarangi. Finkeldey dan Hattemer (2007) menyebutkan bahwa selain faktor dari dalam (fisiologis dan genetis tanaman) nilai outcrossing dipengaruhi oleh faktor luar seperti kehadiran agen penyerbuk de- 
ngan pola aktivitasnya, sinkronisasi pembungaan dan kerapatan tegakan.

Gugurnya ovule sering diakibatkan oleh tidak terjadinya fertilisasi karena adanya reaksi inkompatibilitas (Dumas and Knox dalam Owen, 1993). Faktor-faktor yang mempengaruhi keberhasilan pembentukan benih dari ovul (seed set) pada populasi penyerbukan terbuka (outbreeding population) sangatlah banyak diantaranya adalah kerapatan, pola spasial, komposisi pollinator, kemelimpahan pollinator, perilaku pollinator, kondisi lingkungan selama penyerbukan, pemupukan, perkembangan embrio, serta sumber daya yang bisa dipakai untuk pemasakan buah dan benih (Shore dan Barret, 1984). Perbedaan seed set pada lokasi yang berbeda disebabkan oleh faktor genetik, selain itu jasa penyerbukan juga berpengaruh terhadap pola seed set (Aigner, 2004). Tingginya seed set yaitu $85,05 \%$ di Bogor, 94,48\% di Yogyakarta, 99,99\% di Cikampek (Tabel 3) menunjukkan bahwa polong yang terbentuk merupakan hasil dari bunga yang telah terserbuki dengan baik sehingga sebagian besar ovul bunga berkembang menjadi biji, dan diduga bahwa bunga yang ovulnya hanya sedikit yang terserbuki akan gugur atau tidak berkembang menjadi buah masak. Hal ini juga memunculkan dugaan bahwa keterbatasan pollinator atau efektifitas pollinator menyebabkan sebagian besar bunga dalam satu malai tidak terserbuki.

Periode berbunga-berbuah tanaman A. pavonina pohon bervariasi diantara ketiga lokasi yang diamati. Penelitian ini belum bisa mengungkapkan penyebab perbedaan variasi musim berbunga-berbuah di ketiga lokasi, karena tidak dilakukan pengamatan secara detail terhadap faktorfaktor biotik dan abiotik di setiap lokasi pengamatan (Baskorowati et al., 2008). Kozlowski (1971) menyatakan bahwa terjadinya inisiasi bunga dipengaruhi oleh iklim, kondisi tapak dan praktek manajemen. Selanjutnya faktor iklim yang dapat mempengaruhi pembungaan pembuahan diantaranya adalah intensitas matahari (Khan et al., 2005). Sedangkan Singh dan Kushwaha (2006) menyebutkan bahwa pembuahan berkaitan erat dengan periode berhentinya hujan.

\section{KESIMPULAN}

\section{A. Kesimpulan}

1. Berdasarkan struktur bunganya, tanaman $A$. pavonina bersifat hermaphrodites.
2. Perkembangan bunga-buah tanaman A. pavonina yang dimulai dari tunas bunga, bunga, bakal buah/polong, polong muda, polong tua hingga polong pecah, rata-rata mencapai waktu 89 hari atau 3 bulan.

3. Rata-rata tingkat keberhasilan reproduksi tanaman A.pavonina sebesar $0,89 \%$.

\section{B. Saran}

Sebagai sumber biofuel, rata-rata produksi biji saga masih rendah dan masih memiliki potensi untuk ditingkatkan sampai 300\%. Upaya peningkatan produksi biji ini dapat dilakukan dengan meningkatkan keberhasilan pembentukan buah (fruit set) melalui pemahaman tentang karakteristik penyerbukannya, pengelolaan dalam populasi dan keragaman genetik yang tinggi, serta didukung dengan teknik silvikultur yang optimal. Dalam pengembangannya sebagai sumber biofuel masih diperlukan informasi tentang produktifitas dalam skala hutan tanaman, serta potensi minyaknya sebagai bahan bakar.

\section{DAFTAR PUSTAKA}

Adimunca, C. 1988. Keadaan Fisiologis Hati Tikus Putih Strain LMR yang Diberi Ransum Biji Saga Pohon (Adenanthera pavonina Linn). Jurnal Cermin Dunia Kedokteran Volume 51: $20-24$.

Aigner, P.A. 2004. Ecological and Genetic Effects on Demographic Processes: Pollination, Clonality and Seed Production in Dithyrea maritime. Biological Conservation 116: 27-34.

Baskorowati, L., R. Umiyati, N. Kartikawati, A. Rimbawanto dan M. Susanto. 2008. Pembungaan dan Pembuahan Melaleuca cajuputi subsp. Cajuputi Powell Di Kebun Benih Semai Paliyan, Gunungkidul, Yogjakarta. Jurnal Pemuliaan Tanaman Hutan Vol 2 (2) : 189 - 202. Yogjakarta.

Finkeldey, R. dan H.H. Hattemer. 2007. Tropical Forest Genetic.Springer-Verlag. Berlin, Heidelberg.

Heyne, K. 1987. Tumbuhan Berguna Indonesia III. Badan Penelitian dan Pengembangan Kehutanan. Bogor.

House, S. 1977. Reproductive Biology of Eucalypts. In : Eucalypts Ecology, eds Williams, J.E dan J.C.Z. Woinarski, Cambridge University Press. Cambridge. $30-50$ pp.

Kartikawati, N. K. 2008. Pengaruh Tipe Penyerbukan Terhadap Keberhasilan Reproduksi Pada 
Tanaman Melaleuca cajuputi subsp Cajuputi. Jurnal Penelitian Hutan Tanaman Vol 5 (2) : $099-107$.

Khan M.L., P. Bhuyan dan R.S. Tripathi. 2005. Effects of Forest Disturbance on Fruit Set Seed Dispersal and Predation of Rudraksh (Elaecocarpus ganitrus Roxb.) in Northeast India. Current Science Vol 88 No 1.

Kozlowski, T.T. 1971. Growth and Development of Trees. Vol II. Cambial Growth, Root Growth and Reproductive Growth. Academic Press. New York and London.

Kurniaty, R., A.A. Pramono., K.P. Putri dan R.U. Sianturi. 2011. Laporan Hasil Penelitian Program Insentif Peningkatan Kemampuan Peneliti dan Perekayasa Kementerian Riset dan Teknologi Tahun 2011. Tidak diterbitkan.

Lembaga Kimia Nasional. 1983. Hasil Analisis Asam Lemak dari Minyak Biji Saga Pohon. Lembaga Kimia Nasional. Lembaga Ilmu Pengetahuan Indonesia. Bandung.

Moncur, M.W. dan D.J. Boland. 1989. Floral Morphology of Eucalyptus melliodora A. Cunn. Ex Schau. and Comparisons With Other Eucalyptus Spesies. Australian Journal of Botany 37 : $125-135$.

Nerd, A., V. Irijimovich dan Y. Mizrahi. 1998. Phenology, Breeding System and Fruit Development of Argan (Argania spinosa, Sapotaceae) Cultivated in Israel. Economic Botany 52(2):161167.
Owen, J.N., P. Samsathapornkul dan S. Tangmitcharon. 1991. Manual Studying Flowering and Seed Ontogeny in Tropical Forest Seed. ASEAN Canada Tree Seed Centre. Muak-Lek Saraburi 18180. Thailand.

Owens, J.N. 1993. Biological Constraints to Seed Production in Tropical Forest Trees. In Proceedings International Symposium on Genetic Conservation and Production of Tropical Forest Tree Seed. R.M. Drysdale, S.E.T John and A.C. Yapa eds. ASEAN-CANADA Forest Tree Seed Centre. Muak-Lek, Saraburi, Thailand. P 40 - 51.

Sedgley, M. dan A.R. Griffin. 1989. Sexual Reproduction of Tree Crops. Academic Press, London.

Shore, J.S., and S.C.H. Barret. 1984. The Effect of Pollination Intensity and Incompatible Pollen on Seed Set in Turnera ulmifolia (Turneraceae). Canada Journal Botany 621298-1303.

Singh, K.P dan C.P Kushwaha. 2006. Diversity of Flowering and Fruiting Phenology of Trees in A Tropical Deciduous Forest in India. Annals of Botany 97 : 265 - 276.

Timnas Pengembangan Bahan Bakar Minyak Nabati. 2008. Bahan Bakar Nabati, Bahan Bakar Alternatif dari Tumbuhan Sebagai Pengganti Minyak Bumi dan Gas. Penebar Swadaya. Jakarta. Pp. 164. 